\title{
展望 系么ラの测定拉よび評侢方法
}

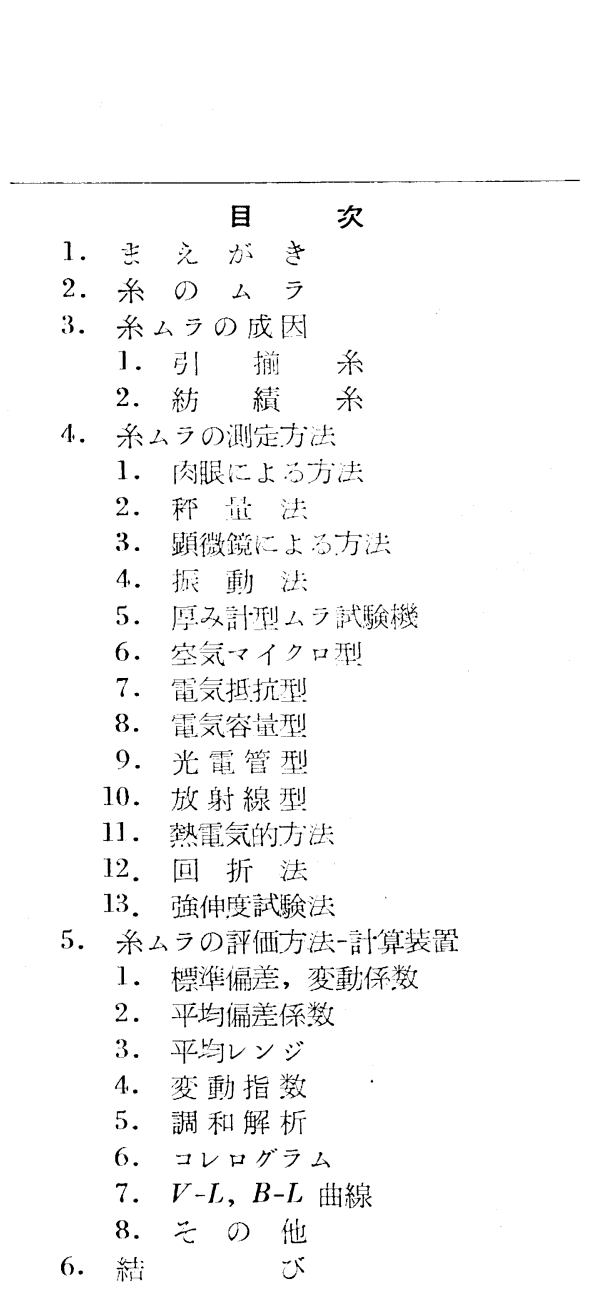

\section{1. まえがき}

紡績工程に揦汸るスライバ，口ービング执よび 系の太さが不均一であるということは相当古くか ら短られて括り，1922年には W. Frenzel がこれ らの測定方法を発表したが，理淪的化解羽しょう という動きは Balls が1928年との太さの变動志周 期的なるのでは圭いかと考えて drafting wave

(ドラフト波)という概念を考案し，綿のローラ ドラフトについて研究したのがその発端といえよ う・以来20有余年，各国化扔いてこれらムラの閐 題は取り上げられ，種々の測定方法や評価方法が 研究されて現在に至っている。しかしながら未だ 決定的な解決沈えられてないようである。

\begin{tabular}{|c|c|c|c|}
\hline 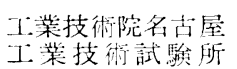 & 野 & 崎 & 長 \\
\hline " & 愛 & 野 & \\
\hline
\end{tabular}

そこでこの研究の一助になればと思い, 先人の研究成 果なできるだけ多く集めてきとめてみようとするのが本 交の目的でる。

\section{2. 米のム}

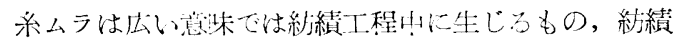
と編織の品間工程凹に先じるもの，扣よび糊付けや染色 の仕上げ工程山に生じるもの去べて含んでいるが，本

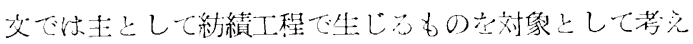
ることにした。

一ロに禾ムラといっても太さ (thicknes), 直往, 断 面積, 単位当りの重量, 色合い, in 当りの撚数, 通宽, フシ, ネップ, カス, 毛羽との他女らゆ后物理的, 化学 的性質についての不均一性(また怯不均質性) が兄の山 に含きれるはずで岁る。しかし普通には太心きた弾位 艮当りの重量の不均一性をいうことが多く，本文でもこ の二つの量芯をとて报うととにする・とのニつの量は 普通添とんど比例し，志た製品に及ぼす影響も上記の諸 性饮比べて最も犬きく，それら諸性質との相関度もき わめて高いことが㙞られている。

\section{3. 糸ムラの成因}

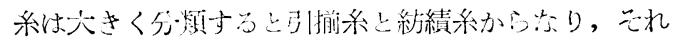
ぞれムラの成区杜異なっている。

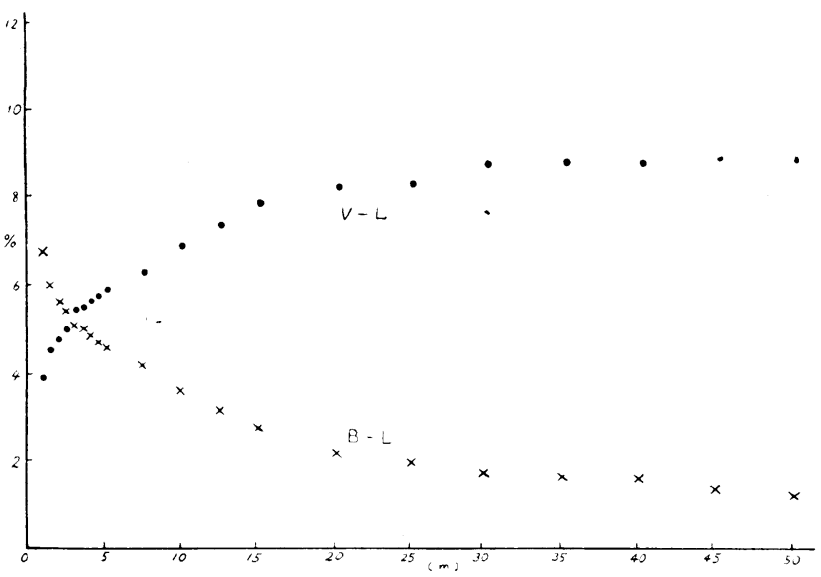

（第1脳）合成纎維引揃系の $V-L, B-L$ 曲線 


\section{1. 引揃 系}

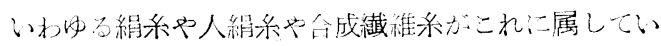

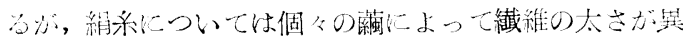

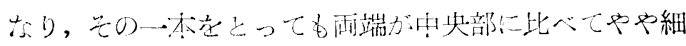
くなっている。合成纎維禾の湯合には紡出ノズルの径の 大小，原液の重合度么ラ，寻たは紡出用ギヤボンプ発 生圧の周期的変動等によってムラ苼生じる。金者らがあ

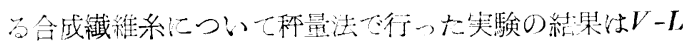

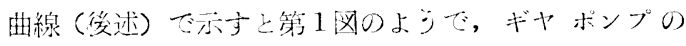

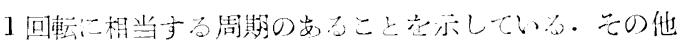

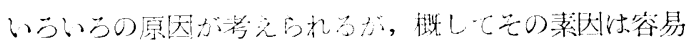

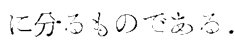

\section{2. 紡 綪 系}

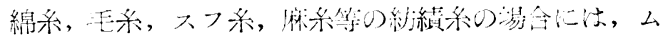

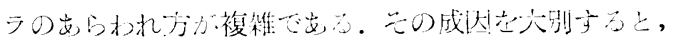

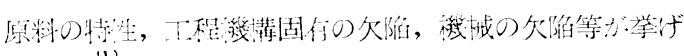

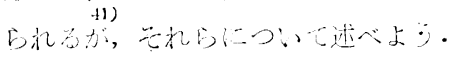

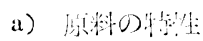

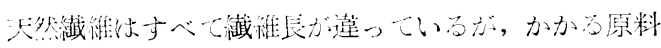

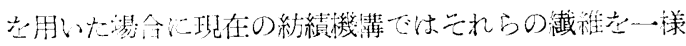

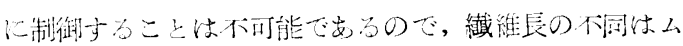
ラの犬きな索团と教えられる。しかし合成瀻触やスフ系

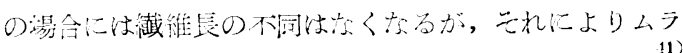
の減台度含が期待される程に悢くないと Marindale 以述べている。瀻維直径志たは太さのバラッキる素团之

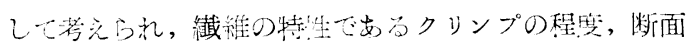
形状(これ法成熟度に䦛連与る)，摩擦持生，弾等等

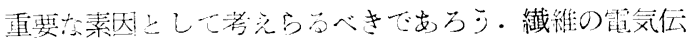

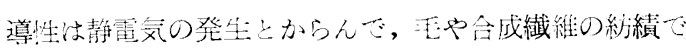
封に注閴上なる・しかしこれら原料の特性の系ムラに

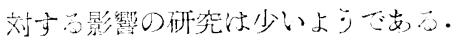

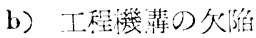

紡續系上いっても多くの種領がをり，これだれ独自の 工程が岁心が，代武的なるりして綿や梳毛のスピニン グシステムと落綿や絠毛のコンデンサスピニングシス デムダ洘沈られる。

间者に閣子る研究の多くはローラドラフトに関する

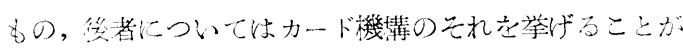

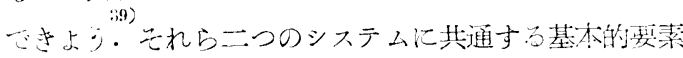

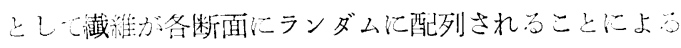

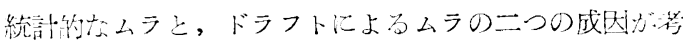

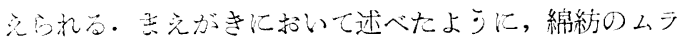
泪然方分研究汢 Balls によって始められ，梳毛紡につい てな Goodings によって着手されたな゙, Balls はローラ
ドラフトの際に瀻維是の短いもの, いわ内る浮遊瀻維な 制御できないために，太さの変動すなわちドラフト波が 生ずると揾染し，Coodings はドラフト波という概念を 用いなかったが，ドラフトによってある波状の太さムラ が形成されると考えた。气の頃 Foster 綿紡のローラ ドラフトについて研究し始めて，Balls の考文交持し

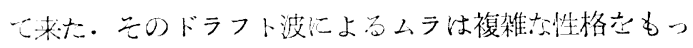

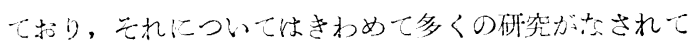

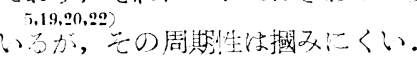

1) ドラフト波 今ここてはドラフト没についての考

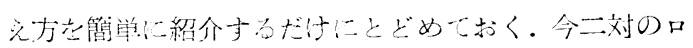

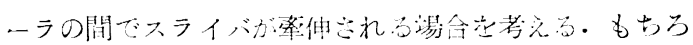

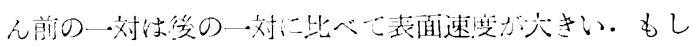

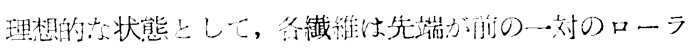

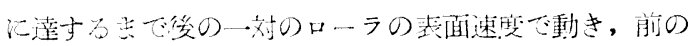

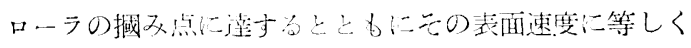

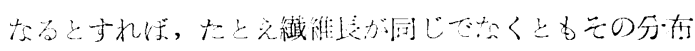

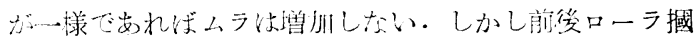

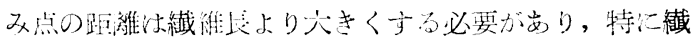

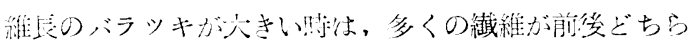
のローラにも制御されず，浮遊瀻維とよばれる状態文経

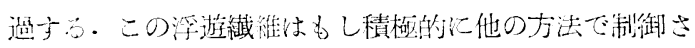
れ沈湯含，口ーラに把持されている瀻踓との摩擦力に 上って動か心れやすい.今年し偶然に太い断面が前の口

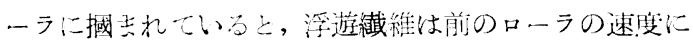

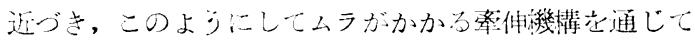
更に䖵調されることに尔る。これによって增加するムラ 点ドラフト波と呼び，紡績機械に見られる中間口ーラの エプロン，針，積檑的に与えられる撚り等はすべてこれ

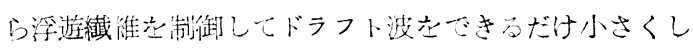
ようという試みで希。

2) 確率的なムラしかしながら1945年頃に Martindale はs

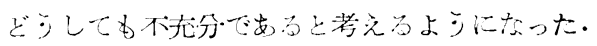

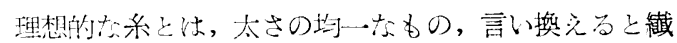
維の太さ老均一七仮定すると，系のどの部分の断面に扎

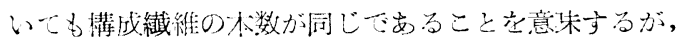

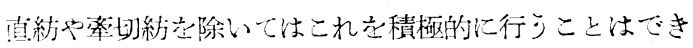

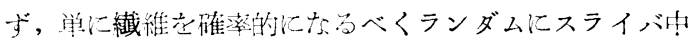
に配列しているに過ぎない，繊維な゙最初にランダムに配 列させる能力淮備工稫に岀って，との後の工程ではえ れ以上に瀻維の配列状態主改良する能力がない。

ある一個の緎維がどの断面に配列されるかという確率 
が同じであると仮定した場合，かかる多数の鑯維が各断 面酒列される時，その本数の分右はポアソン分存で まりその平均本数が $N$ 本であれば, その模潐偏差は $\checkmark N$ で, その本数の变動係数 $V N$ を\%で表わすと

$$
V_{N}=\frac{V N}{N} \times 100=\frac{100}{V N}
$$

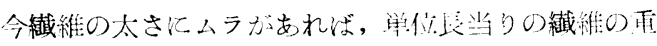

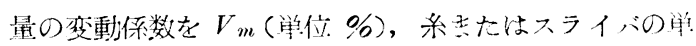

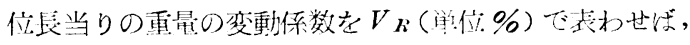
次式がえられる。

$$
V_{R}^{2}=\frac{(100)^{2}}{N}+-\frac{\left(V_{m}\right)^{2}}{N}
$$

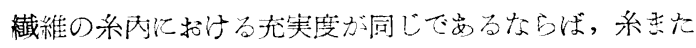
はスライバの断面積は単位長当りの重量に比例するから 系またはスライバ招よび繊維のそれぞれの断面積の变動 係数を $V_{a}, V_{A}$ とすると

$$
V_{n}^{2}=\frac{(100)^{2}}{N}+\frac{\left(V_{A}\right)^{2}}{N}
$$

$V_{d}$ を繊維直径の变動係数として $V_{A}=2 V_{d}$ と招くと (2) 式は

$$
V_{a}=\frac{100 \sqrt{1+0.0004 V_{a}^{2}}}{V_{N}}
$$

これら 3 式中，実用的には単位登当りの重量の変動に ついて測定する湯合が多いから（1）式が都合がよい。

これらの式から分るように，操仡方法や、程機構が炕 とえ完全であっても番手が細くならにつれてムラは大き くなる・このランダム配列によるムラは配列が皘極的で ない限り除去することのできない最低のもので希る。

系ムラの実際の測定値には上記のムラにドラフトやそ の他のいるんな影響によるるのが重なり合っているわけ である・な拓前に述べたように直紡系は原料の配列がき わめて一様であり，この確率的なムラが無視できるとい う利点をもち，実際の測定結果もきわめてムラの少い系 がえられる。

\section{c) 機械の欠陷}

ムラの原因となる機械の久楩は枚挙にいと委ないほど である・ホッバに招ける秤量のあやまり，中間フィード ローラ等の取付不良, 諸口-ラの偏心等によって準備工 程でスライバにムラを生じ, 練衡や精紡の工程では纎維 の動きを制御するローラの偏心, 被覆レザやゴムの硬

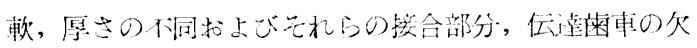

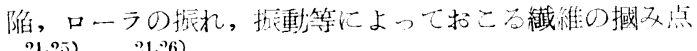
や翌面速度の变動が原因上なって系ムラが生じるが，只

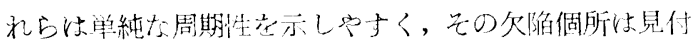
けやすい。 d) その他

上訅の他に挙げられるものとして相対湿度がある。

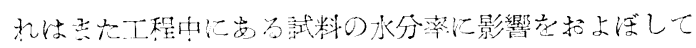

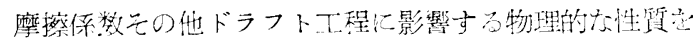
变化させやすく, 静霍気の発生もムラの原因々なるが艺

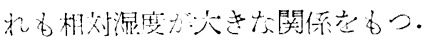

\section{4. 米ムラの測定方法}

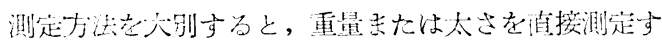
るものと, それらに比例なるすのやとれと相関度の高い

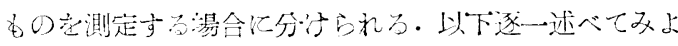
丂.

\section{1. 肉眼に上るオ法}

a) セリプレン法

黑色の板志た注黑色ビロードて被った板汇約 $100 \mathrm{yd}$ の系老定間隔に卷きつけ, 視覚により標準䧧料(通常军 真板）と比べて 1, 2,3，4号，4号飞達しないるの（徉

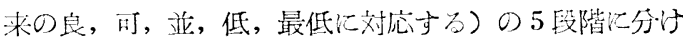
る。そして各試料から4個づつ取り，上記の段階江対応 させて点数をつけ，合計の総点をもって系么ラを表示し 上うとするのである。熟練者によるこの力法の感度注非 常に高いが，系ムラの表われ方が一様でないから，標潗 試料との比較だけでは客観性を欠く括とれがあるが， JIS この他従来の品筫検查に法末だのの方法が用いら 和ている。

\section{b)メリヤス編法}

1本の系を等張力，等編目密度でメリヤス編化する と，系ムラがきわめてよく分る。そしてこの方法は定性 的, 主観的ではあるが, 系ムラ測定の目的炕合致し, 感㝜は平均偏差倸数で約 $1 \%$ 差が判別できる程であ りこの程度の差の有意性を直径測定によって確かめる には約 800 個の測定個数が必要であるといわれる。

\section{2. 秤量法}

a) 定長切断法

適当な試長比断してそれらを种量する力法は，切断 や科量の操作がともに正確で, 測定に要する时間を考见 亿入れた计れば理想的な直接法であるが，实際には操作 飞伴って誤差が入り，その上相当の时間々学力堂す

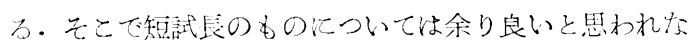
いふ，試长志长くして長周期のムラン調べるのには好都 合故号。

b) 力七切断法 (Cut Hank Method)

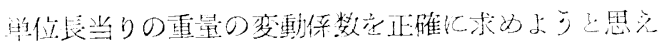
快莫大な試料が要る・ここで a)のち法をるっと要領よ 
くやろうというのが朴節に述べるあのだ，梳毛の糸持 よびスライバについて Martindale の考案したものであ .

\section{第2四のよ}

うな普通のひ びる車の-.つ の腕にl in 余 りの川ノの鋼鉄 製バー $B$ 在 固定方名・一 周 36 in は平衡鍾であ る. $A$ と $B$ は共に糸の艮 さ方向化正し

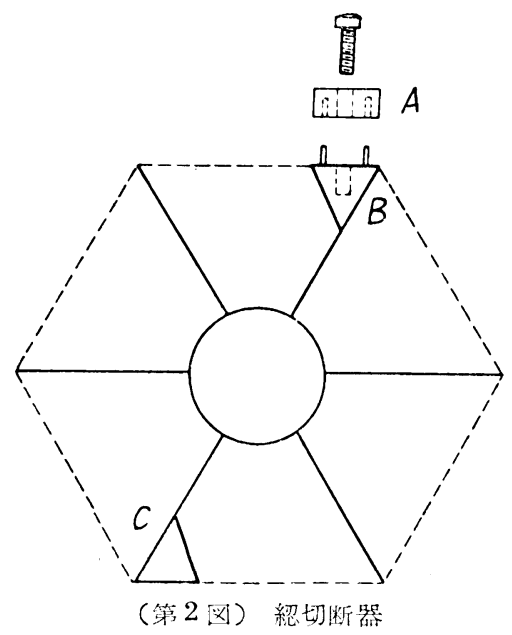

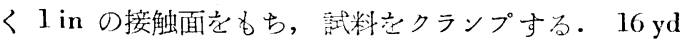
の糸をこのかせに䖭きつけて， $B$ 上に $A$ をはめてクラ ンプし，Aの承端にて剃双により系䘮切断する。この 操作老 $n$ 回行い

1 in 划断された群の重量 $\cdots m_{1}, m_{2}, \cdots \cdots m_{n}$

35 in 群の重量 $\cdot M_{1}, M_{2}, \cdots \cdots M_{n}$

とする・今 $\Sigma M / \Sigma m=R$ と括き，16本から成るひびる走 16 本合系と考える。すると $M_{1} / R, M_{2} / R, \cdots M_{n} / R$ 㥙 16 本合系の単位長当りの平均重量と見做すことができ る.かくして $\left(m_{1}-M_{1} / R\right)$ は 16 本合系 $1 \mathrm{yd}$ 試料から 選んだ 1 inの部分の重量の単位脣当り平均重量からの 偏美となる。他のものについてる同じで，16本合糸の $1 \mathrm{yd}$ 長內に和ける単位長当りの重量の櫒準偏差は

$$
\sqrt{\frac{\sum(m-M / R)^{2}}{n-1}}
$$

この16本を構成する単禾がランダムに選ばれたと仮定 することができれば，単糸の棒準偏差は

$$
\sqrt{\frac{\sum(n-M / R)}{16(n-1)}}
$$

そこで $n=100$ とすると， 1 in の重量ムラを $1600 \mathrm{yd}$ の試料について测定することになり，これ䘮㨁接法でや ると 2 人で 1 月かかるといわれる。

\section{3. 顯微鏡による方法}

a) 直径測定法

毛羽や焦点深点の関係から明確な值が得がたくて，よ い值をうるには熟練を要する・

b) 断面繊維数言十数法

禾をごく短かく切断して，それをいくつかに分割して 顕徽鏡下で棓数する方法であるが，繊維断面積の大小分
有が一様である必要がある。

\section{4. 振 動 法}

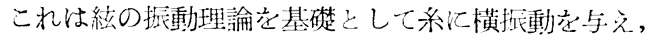
系ムラを报動の節間距離の变化によって求めるものでま る・市なわら線密度 $g$ の系を横舶動させて定常波を作 り, その洔の禾にかかる張力 $T$ 招動数 $n$, 波数 $a$, 試 長 $l$ とすと，それらの間に

$$
n=\begin{array}{ll}
a \\
l
\end{array}
$$

の関係がある，そこだ $l, n, a, T$ が分れば線密客 $g$ 在 求めることができる。こうして系の重量が分る。

上訅の方法いずれも系の等位長当りの重量志た注太さ の直接測定法であるがこれから述べる間接法は糸の太 さに比例するものをいらいらの手段によって梌出し，ム

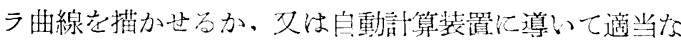
統計量を求め上うとするのである.

\section{5. 厚み計型ムラ試験機}

a) 固定シュー型

英国にて考案された愿名計型の原理は，固定シュー （shoe）上に系きたはスライバ妾走らせ，上から適当な

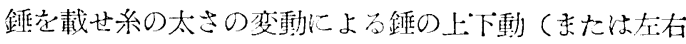
動) 学梌知することによって太さムラを測定しようとす るのである。

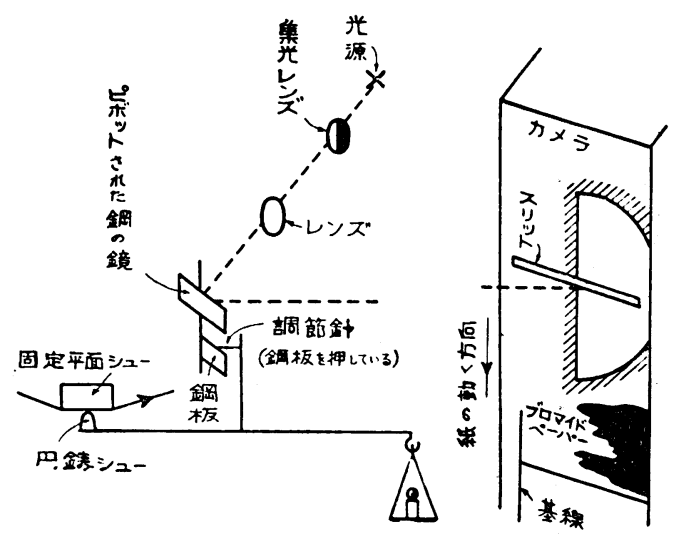

（第3困）感光式系么ラ試験機

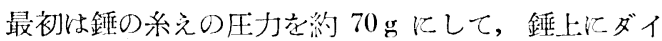
ヤルゲージをつけて針のフレからムラを推定した. そ の後漸次改良されて, 第 5 図のように上下動の拡大装圆 として光挺子党利用したり，第6四のように挺子を用い たりして，結局この両者を組合わせて第3図の型となっ た・これが感光式系ムラ試験機の原理図で,シュー拈

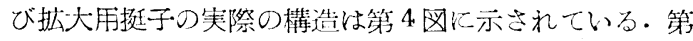
4図にて $A$ 注固定平面シュー，Bは $A$ との接解面が $9 / 32$ in の曲率半径の川筒シュー，F はピボットされた鐝 
の反射鏡， $E$ 注 $F$ と共軸の鋼板， $D$ は調節針にしてマ イクロメータ放じ $Q$ 妾用いて $E$ と $D$ の間隔变变る

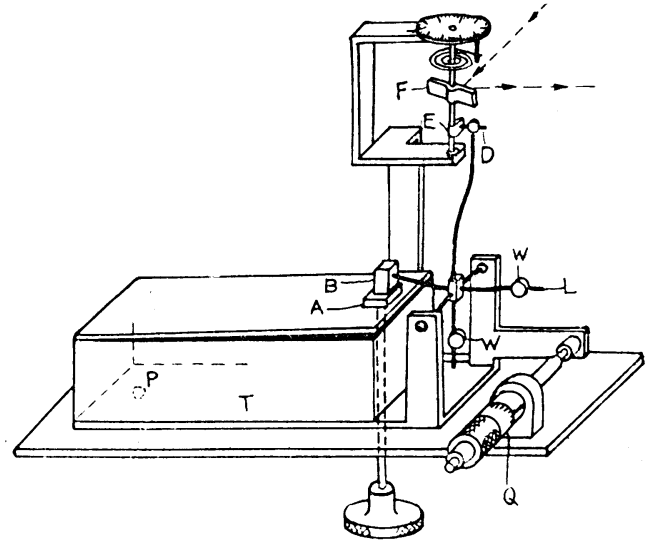

（第４脑）感光式試験機のムラ測定部

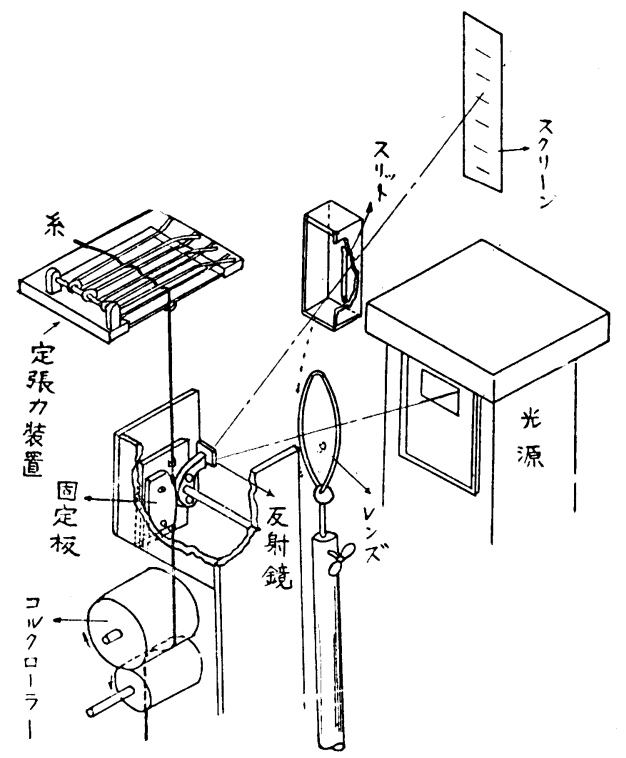

（第５図）Saxl のムラ試験機

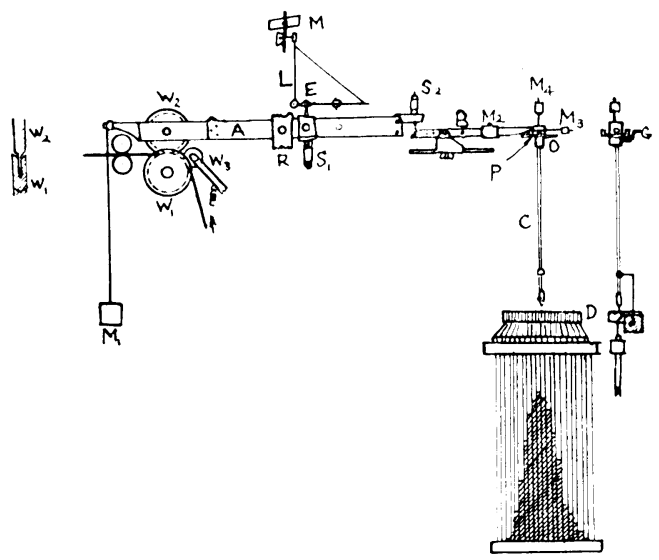

(第6図) スライバロービング用シューテス タ把よび積算装置

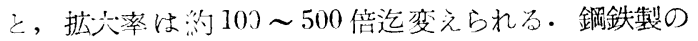
箱 $T$ は土台上にある 3 個の鋼球に載せられてあり, そ のうちP は移動しないように箱と土台にある円錐状の 所欢はまっている。 そこで $T$ は $Q$ によって $P$ を 中心として回転することができ，Fと $E$ の軸は土台に 固定してあるために，Qの回転により上記のょうに桩大 率变化できるのである. 零点の調節は $A$ の固定され ているものが虺い板ば权で, その高さはその下にある垂 淔衫しよ一て加減されるから压力は約 $2.5 \mathrm{~g}$ にして $1 \mathrm{~min}$ 聞に $100 \mathrm{in}$ 采での染出速度でムラの測定ができ るようになっている。このテスタは糸用のものである が，スライバやロービングを含めて調ベるには次項の溝 付ローラ型妾用いる。

b) 㴖付ローラ型

前垻の固定シュー型は撚りの蛄い系には利用できる が，然りの甘いスライバやロービングでは摩擦力によっ て試料が引伸ばされたり，切れたり，また扁平になったり するので測定の対称量があいまいになる。これらの点 を除くために考えられたのが本項に述べる溝付口ーラ型! で, 溝中に試料を走らせ, その上に一定荷重のローラを 載せ，「Fの溝付ローラを積極的に回転させ，荷重ローラ の動き文機械的, または電気的 (例：抵拀線歪計型)に 拡大增门しょうとするのである・現在スライバ用とし て利用されている Saco-Lowell や第7困の Paciúic テ

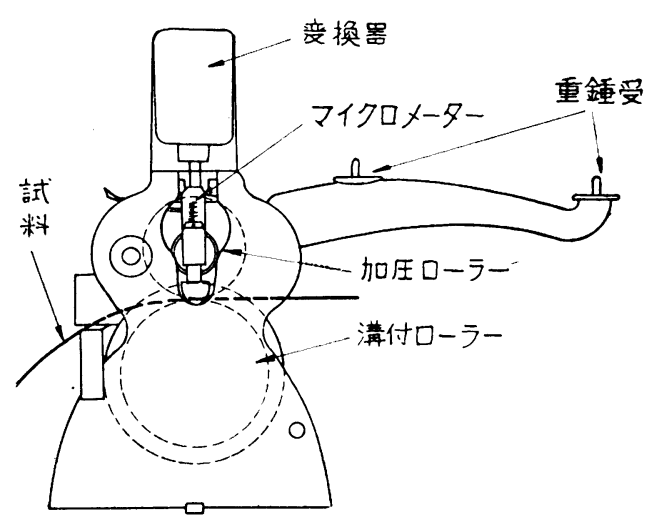

（第7図）Pacific ムラ試験機の娭知部

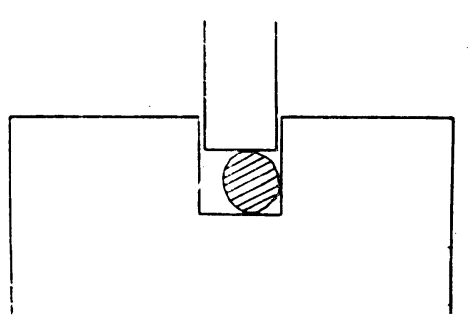

スタはこれであ る.この方式は, 扰大率を上げる にはローラの偏 心を極力少くし なければならな いことと, 撚り （第 8 [図）满中の試料 によって第 8 図 
のように溝中にできる隙間が異なり誤差を生じ易い。

\section{6. 空気マイクロ型}

第9网のように流出ノズル $N_{2}$ に試料を走らせ, 流入 ノズル $N_{1}$ から一定圧の空気を涘って，試料による $N_{2}$ ノズルの流出抵抗の变化により， $N_{1}$ と $N_{2}$ 間の测定案

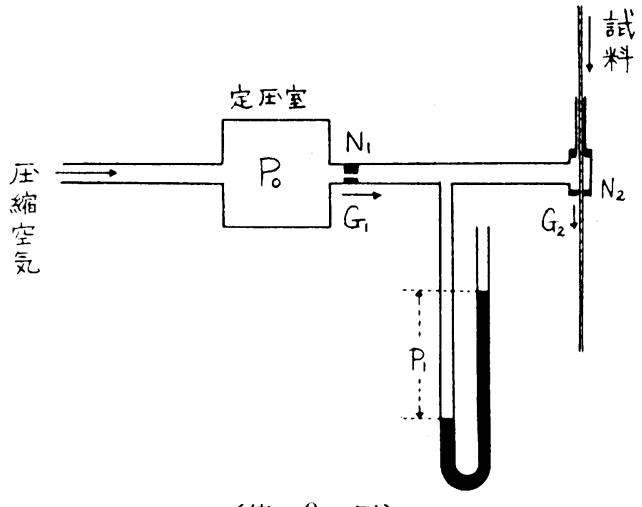

(第，9网）

空気マイクロ型ムラ試験機の原理圈

の压力が变動する．との压力变動を水桂や水銀桂のマ， メータの動きに变えたり，ペローズを用いてペン紊作動 させたり，抵抗線歪計等によって電気的量に変搰してム ラを梌出する・空気マイクロ型には空気を流入させる真 空式と流出させる圧力式があり, 压力式の中にゲージ父 压て $1 \mathrm{~kg} / \mathrm{cm} 2$ 以下の低压式とそれ以上の高压式が尔 b.

流出（測定）ノズルとして，第10园のように片ノズル と雨ノズルがある・片ノズルを用う際に虫，導系ノズ ルからの空気の洩れによる誤差を防ぐために，そのノズ ルな番手に合せて細長くしたり，ラビリンズ皇作った り，水銀中に浸したりする必芜があるが，えの特長は短
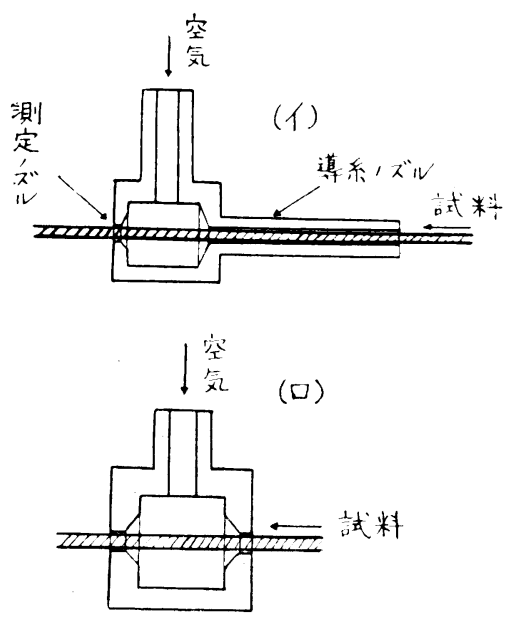

（1）片ノズル (口) 阿口ノメ゙ル

(第 10 忷) ノ ズルの型
衤期のムラの検出で きることである。両 ノズルを用いると，

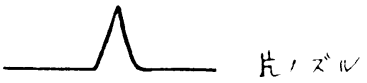
空気の洩れによる誤 琹の問題がない代り に，第11四のように

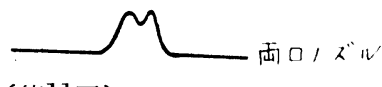
（第11戍）ネップのムラ曲線 一つのネップを 2 個に勘定し，一般に検出できるムラの 周期が長くなる・

きた連続測定をする際には，試験機の動的造随性が高 度に要求される・そのために浪測定公の容積をできるだ け小さくし，空気の流量の多いことが必要であるが，訅 録部の追随性ももちらん良くしなければならない。

一般に記録装置として，ベローズとペン， 19,5゙ローズと インダクタンス, 抵抗線雪計とペン書きオッシ年等が利

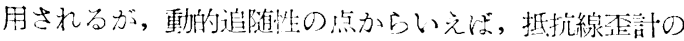
利用価值が大きい（第12四)
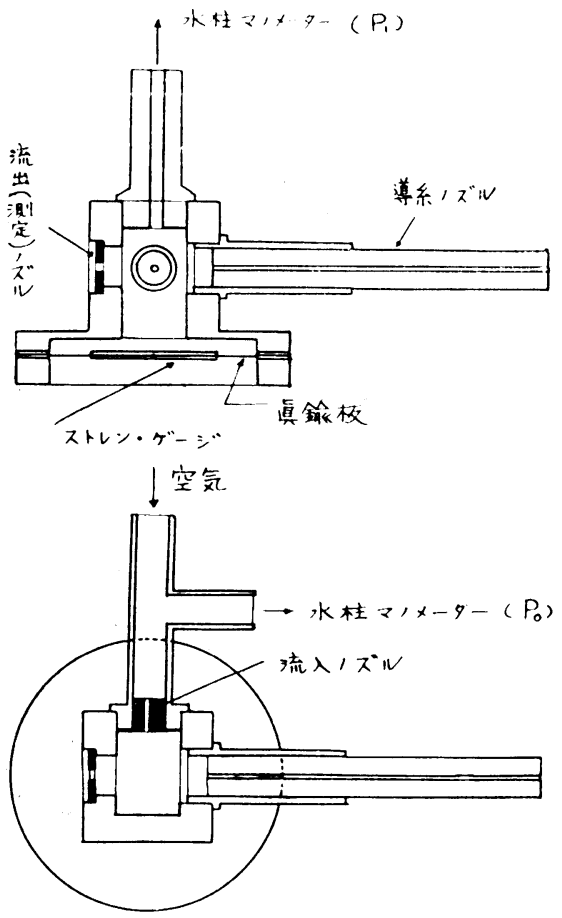

(第 12 図)

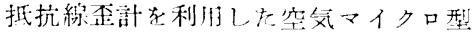
ムラ武験機の検知部

\section{7. 贯気抵抗型}

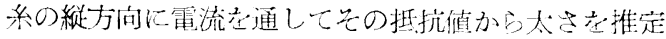
しょうとするのであるが，糸の電気伝導䝿は一般に小心

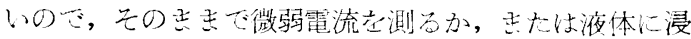

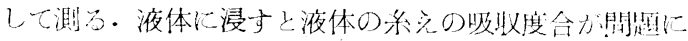

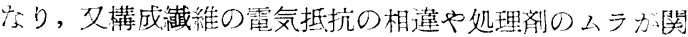


倸してくる。

\section{8. 電気容量型}

原理は固定した空気コンデンサの閆陌に陚料を走らせ ることによって生ずる容量の变化を測定しょうとするの であって，まる条件の下では，容量の変化は試料の重量 飞比例している.この容量の変化は二つの方法によって 検出される。

a）共挔回路法，b） A.C. 容量ブリッジ法

a) 共振回路法

周波数 $f \mathrm{c} / \mathrm{s}$ の電圧 $e$ が第 13 図（イ）の同調回路に
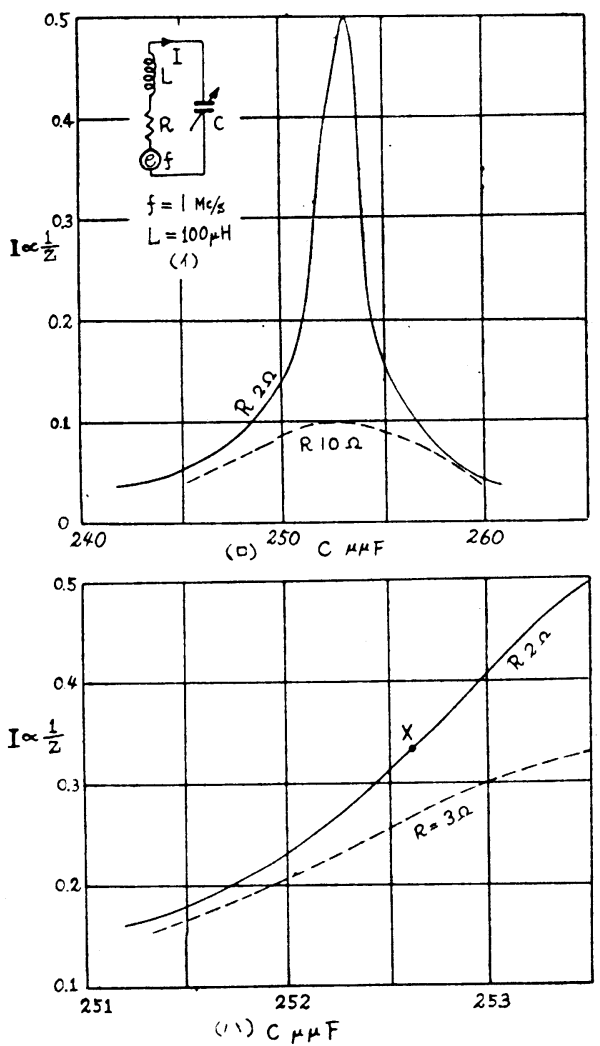

（第 13 汹） 共振回路の特性

かかると，電流忹网（口）の曲線の上うに容量 $C$ に

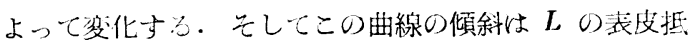
抗 $R$ により決まるから，高感度にするには $R$ をでき るだけ小さくせねばならない，測定に利用するのは，共 执値前後の直線部分で, 回路は共抾㭙容量上り小さい $C$ の值で off-turnされる。この限界範网に批汁る電流の 变動は同図（ハ）に示しててをる。

測定部の蓄電器采は可变上固定のコンデンサ去亚列に

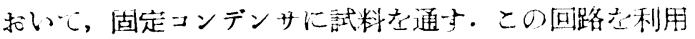
するに際して注意すると上は，固定コンデンサの容量吉 適当に決めて試料の太さに対して測定系の全容量が共捺
值にならないようにすることと，回路が試料を通す前か ら作動されて晾り, 試料を通してムラを検出しょうとす る時，谪当な检出回路を作って電流の定常部分をバラン スさせ极な゙ならととである。この回路の実用例はUster である。

b） A. C. 容量ブリッジ法

このブリッジは特別飞卷いた変圧器と平衡用のバリコ ンから成り，トランスの 2 次側のインダクタンス $L$ 拉 よび各 2 次側と 1 次側の相互インダクタンス $M$ はそれ ぞれ全く同じになるように作る。すると第14四の理論回

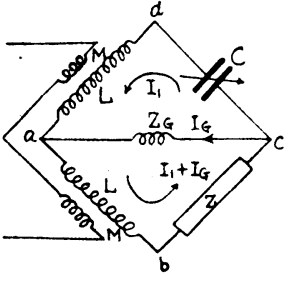

理論回路
共用回路

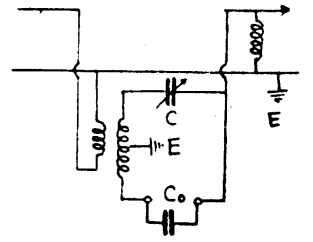

（第 14 汹） Fielden Bridge [回路

路に扔いて, 発拢器からの入力は 2 次側 $b a$ 之 $a d$ に同 じ電圧索誘起し， $C$ がリアクタンス $Z$ 亿丁度等しいよ シに調整してあると，abca と $a c d a$ 汇相等しい循環電 流が流れ，コイル $Z_{G}$ に打ける出力は 0 になる。第 14

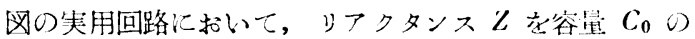
固定コンデンサとして，バリコンが $C=C_{0}$ に調整して あればブリッジはバランスしている。

ここで試料を $C_{0}$ の間隙に入れると, 容量の变化 $\left(C_{t}-\right.$ $\left.C_{0}\right)$ に比例した出力電流 $I_{g}$ が流れることになる。るち ろん入力発振器の周波数扰よび犬きさが一定で, 出力四 增巾器が安定して扰り, 利得 (gain) 一定, 作動が線型 でなけれげいけないことは $(a) （ b)$ いずれと打いても 同じである。

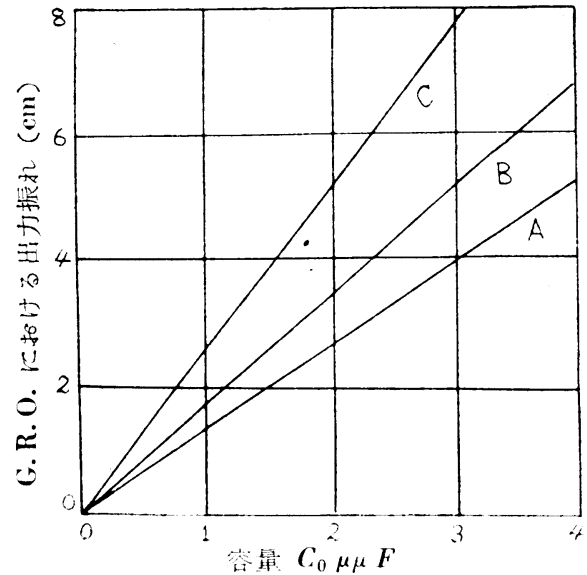

A : Low Gain, B: Medium Gain, C: High Gain （第15忷） Fielden Bridge 式容量型の特性 


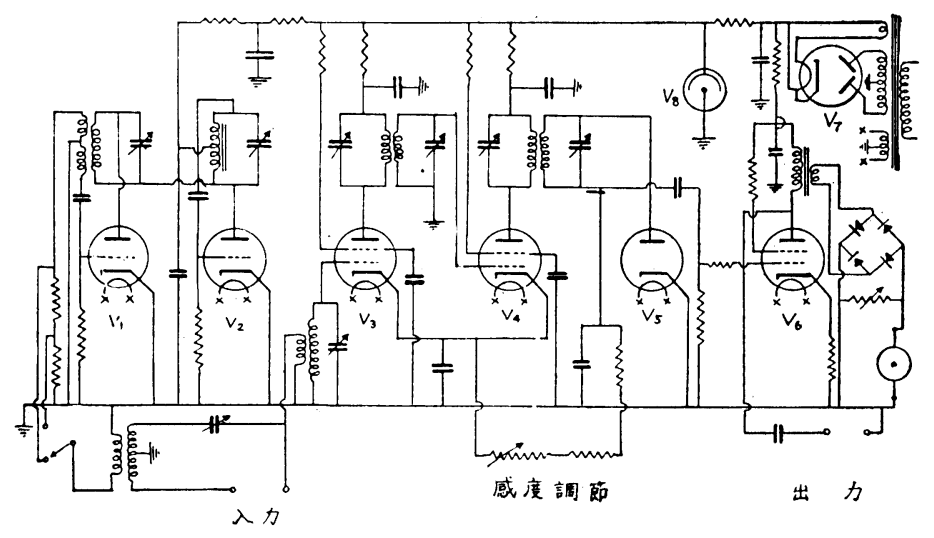

（第 16 困） Fielden Bridge 增巾回路
禾洞期的汇駆動されるドラムワイ ンダ $W$ によって定速で卷取られる。 光源からの光路は

イ）光源 $I_{1} \rightarrow$ プリズム $G_{1} \rightarrow$ 糸 $\rightarrow$ プリ ズム $G_{\mathbf{2}} \rightarrow$ 光電管 $V_{1}$

口) 光源 $I_{1} \rightarrow$ 調節シヤッター $K \rightarrow$ 平 衡光電管 $V_{2}$

委た光電管からの信号の通路は

1）信号 $\rightarrow$ 感度制御 $\rightarrow$ channel $1 \rightarrow$ 訑 録計 1 (信号をとのまま应大)

口) 信号 $\rightarrow$ 感度制御 $\rightarrow$ channel $1 \rightarrow$ channel 2 $\rightarrow$ 記録計 2 （短周期么 ラを除外)

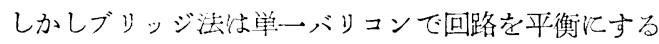
ことができる上に，共振型のように全容量が所要の值以 上になって，そのために俁差のるという心配はない。

ブリッジ回路の特性法第15図に示して炭る。他の条件 がみたされて执れば，共振回路に比べて良いよう思わ れる. 回路の実用例としては Fielden-Walker がもり, 同機のブリッジの増巾回路垁第16図に示した.

これら容量型の久点は, 水の誘電率が纎維に比べて数 十倍に大きいため含水量がムラに大きく影響し，また緎 維の種類によって誘事率が異なるために, 瀻維の混合比 によってムラの出方がちがって来たり，また温度によっ て発报周波数が变化しやすいことである。

しかし感度が良くて取扱い容易な上に，言算装置が取 付けやすいために, 上訅の欠点にもかかわらず世界的に 広く利用されて括り，最近は糸，スライバのみならずラ ップのムラ測定にも使われ始めている。

\section{9. 光電管型}

光源と光電管の間に糸を走らせ, 禾のために光電管に 達する光量が変わるのを利用したすので, 多くの人によ り試みられている・他のいろいるな測定方法が, 概して 糸の断面積に比例する量を測っているのに対して, この 方法は直径比例する量を测っているから，断面の形や 緎維の配列状態に大いに影響される.従ってスライバや ロービングには具合が悪い：また系の場合です，撚りの 甘い引揃系では断面が扁平になって，らせんを描くこと により見かけのムラを生じから，その部分のみ仮撚り を与える方法が考えられている。かかる影響をさけるた めに避力な光線を用いて試粼に照射し, 直径に質量の影 梸を加えた量を測定することがこころみられている。 と れがここ炕述べようとするFilometerであるが，結果と 㨁径または質量との関係は簡単でないであるう.（第17 困参照)

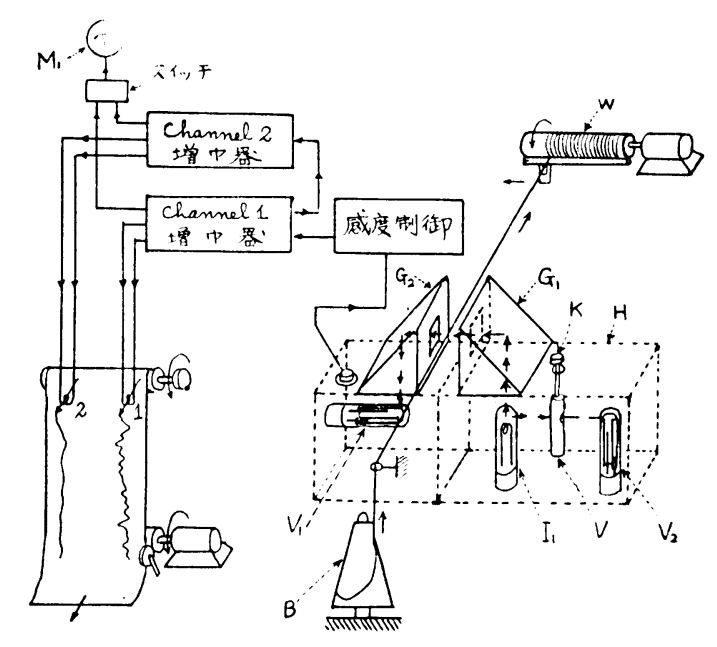

（第17闵）光電管型系ムラ試験機 Filometer

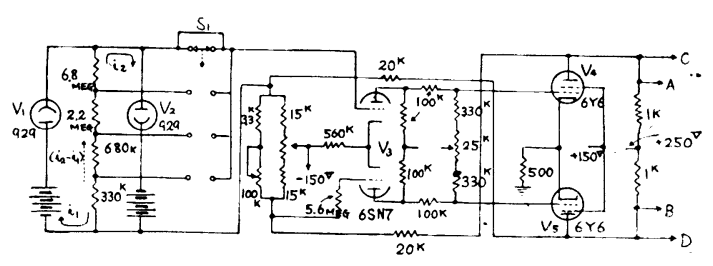

$A B$ 積分回路人

$C D$ channel 1 のペン モーター

（第18図）感度制御把よび channel 1 用増巾回路

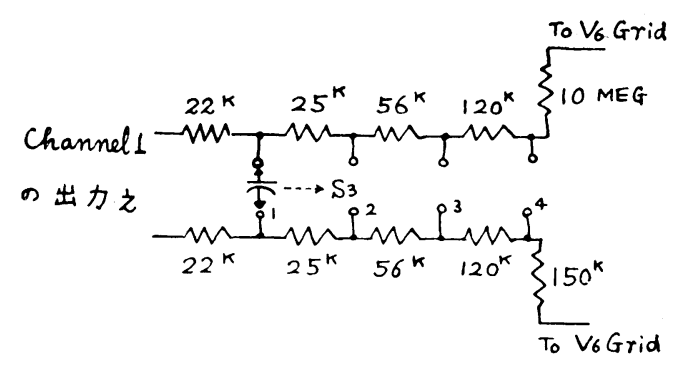

（第 19 図）積 分 回 路 


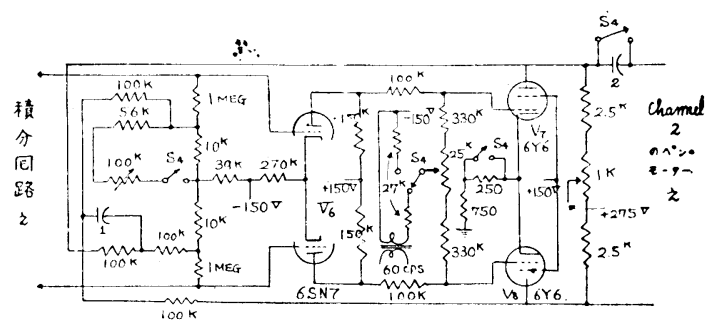

（第 20 図） channel 2 增巾回路

口）の通路汇て channel 1(第 18 図) と channel 2(第 20 四）の間第19四の積分回路が入れて名る。これは 抵抗と容量の緗合で，本質には low-pass filter で岁る。 このように短周期ムラを除外し，長周期ムラのみを㭘出 する方法は光電管型のみならず他の電気的方法にも多く 利用されている.

\section{0. 放射線 型}

光を利用する場合には前項のように断面の形飞影響さ れやすいのに対して，放射線の吸収は放射線源之計数管 の閌にある試料の售量のみにより，とれと簡単な関係が ある。放射線の種類としては，繊維の容量が小さくま た感度を晾る点から $\beta$-線を用いた方が良い。現在の 段階としては糸よりも光電管型の適用できないスライバ やラップに用いるのが好都合である。
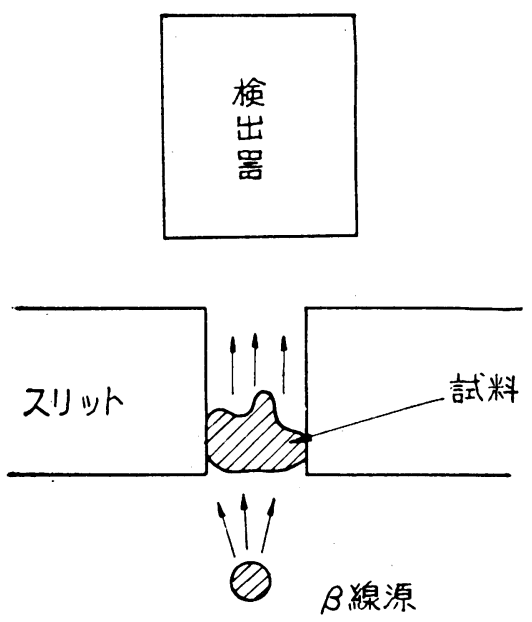

（第 21 図）放射線型么ラ試験機の原理図

第21四のようと試料はスリット間を走らせる・紙や薄 板を測定するのに比べて，スリット中の瀻維の配列状態 は複雑であるが, 実験の結果は空㭞を大きく作らないか ぎりその配列状態の影響はきわめて小さく，むしろ就料

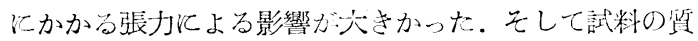
量と簡篻な関係をなすことが分ったが，放射線型の久点 は放射線の放射ムラである。

一般飞放射線ムラはポアソン分布をなすから，ての 測定誤差は計数量を $N$ とすると $\sqrt{N}$ であり, 測定誤
差を1\%にするには $N=10000$ なるととが必要である。 しかしガイガ カウンタの分解時間は $10^{-4} \sec$ 程度であ るからカウンタを用いる限り，きわめて小さい周波数の 波でないと追随できない。この点から電離函，末たはシ ンチレーション カウンタ（分解時間 $10^{-8} \sec$ )を用いた 方が良い。

\section{1. 熱電気的方法}

熱電堆のスリット前に颃いて糸を均一な艮力で走らせ ると，糸の存在のために輻射熱の通過が好げられ，系の

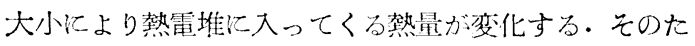
めに熱電堆に生ずる電流が变化し, 電流は反照型检流部 を用いて記録用カメラのドラム上に反射鏡からの光束を 映像させることにより測定される・この㭙二つの熱電堆 を直角に扣いてその合成雷流を求める。普通の検流計の 固有周期は長いので，捙続测定に対してはこの方法は不

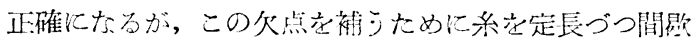
的に引張って，ての等の鏡の定常的フレ究記録させるよ うにしてまる。

\section{2. 回折法}

この方法は1824年 Young が提案し, Ewlesにより改 良されたものであるが，Matthew が更に改良して系直 径の測定に利用したものである.スリット光源からの光 がスリットに平行していて, また相互に近似的に平行に 配列された韯維束を通過すると，スクリーンに一列の 明䕎の光带が瀻維軸に垂直な力向に対称に拡がっている のが見られる. 回折㻎論から光帯の明暗の間隔と繊維の 径の間に既知の関係がある・もちろん系の直経の測定に は，装置を少し改良しなければならないが，結果は余り 良くない．この方法は一定の周辺をすつ亞麻系について なされたが，毛羽のある系（たとえば梳毛糸）について は不向きである。

\section{3. 强伸度試験法}

a) 抗張力法

系の長さに沿って定長つつ引張試験をして抗張力を求 める. 系ムラが系の強度の点から問題にされる時には, この方法が直接的で有效である. 処理中の禾切れと强度 ムラとの関係もある程度理論つけられている。これの曲 線のある試長に打ける最低点を結んだものであるから， その抗裴力曲線の波の大きいことのみならず，低いこと はムラの大きいことを示している. として前者は試長以 上の周期をるつムラの目立つことを示し, 後者は試長以 ・下の周期をるつムラのあることを示ず・この試験を能率 的に行うのに，モスクロップやUster の連続引張試験機 等がある。 
b）定伸長張力法

棚澺式連続引張試駩機では，6\%伸長时の張力を $10 \mathrm{~m}$ 每に 100 回記録する上うとなっている・前们真と同様な考 え方ができるが，非破壞であることが特長でるる。

\section{5. 米ムラの評価方法一計算裝置}

4 節でムラの測定方法を述べたがこうして得られた 測定値やムラ曲線（またはムラ試験の出力）を如何に処 归するかということ法，前者に劣らず重重な問題であ る. るちろん研究目的汇よって処理の程度は異なる心゙， いずれにしても古来いらいるの統誯的方法によってえの 科傮方法が研究されて来た。

种星法きたはムラ曲線から得られた一連の測定值を

$x_{1}, x_{i}, \cdots \cdots x_{i}, \cdots \cdots x_{n}$

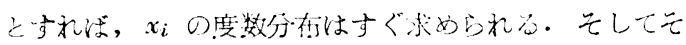

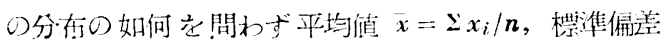

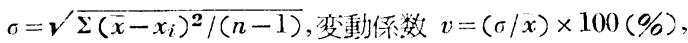
扰上び相対分散 $V=(\sigma / x)^{2}$ 牥計算に上って求められ

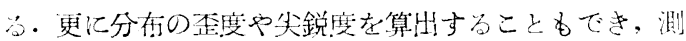

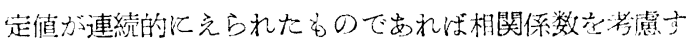
ることになるが，分有の性質はと水ら統諻を量单独に取 りあげて説明されうるるのではなく，それら在同时化洘

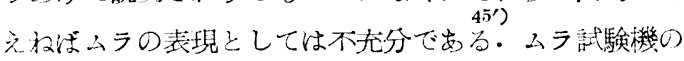
出力は，ペンによりムラ曲線を描か女，とれを手により 処埋することもできるが，ムラ試験機江計算装置を附加 して各種の統計量を自動的に算出することにょって，て れらを計算で求める时間と労力を哇ぶことする研究も なされてい\%。

\section{1. 標準偏差, 变動係数}

これらの量は統計的飞用いてきかめて便利な量であ り，系の全長にわたって測定点をランダムにとってとの 測定值から計算することができる。この時平均偏差の湯 合と買なって偏差を求める削似平均值を求めなくとも誤 差を生じないて計算できるから便利であるか，直接に行 うと相当の労力を必要とする。

a) 度数分布法

統計計算で普通に行われるように，度数分布が機械的 に求められれば, 簡単に平均値, 槽淮偏差を求めること がでる。すなわち測定値を間隔 $i$ 毎敒分割し，それ ぞれの段階の測数值の数を $f$, 測定値 $X_{0}$ を中点とする

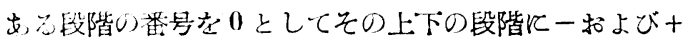

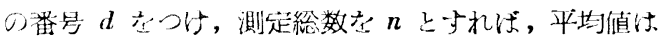

$$
X=X_{0}+(\Sigma f d)_{i} / n
$$

槽淮偏嫊は

$$
\sigma=i_{1} \frac{\Sigma f d^{2}}{n}-\left(\frac{\sum f d}{n}\right)^{2}
$$

によって計算でき。.

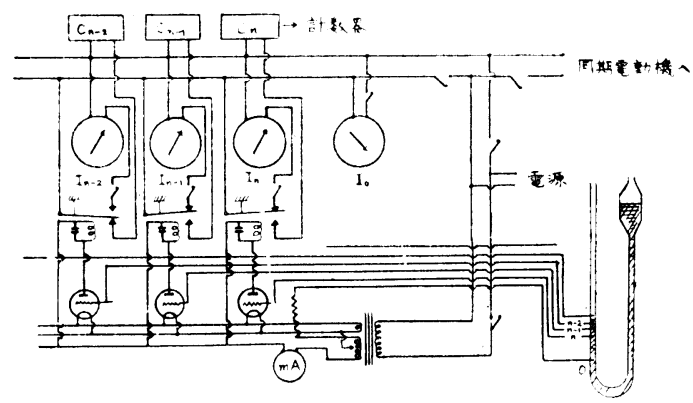

（第 22 汹）森式么ラ試駼機の積算装圈

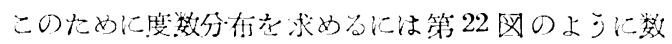
個の水銀接点々多数の我気㭙部老用い，それぞれの段階 內に測定点がある时間を積分することによる方式があ $3^{46)}$ ( (1)

きたこの上うに时間を積分する代りにこれぞれの段階 汇水銀柱や指針の触れたり，委たは離れたりする度数去

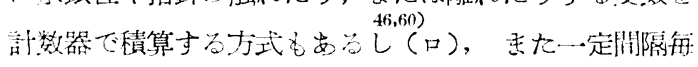
に白動的に電流を通し，その时の值の属寸る段階の部数 器が回転する上引にも設計できる・(ハ)(第23四)後の

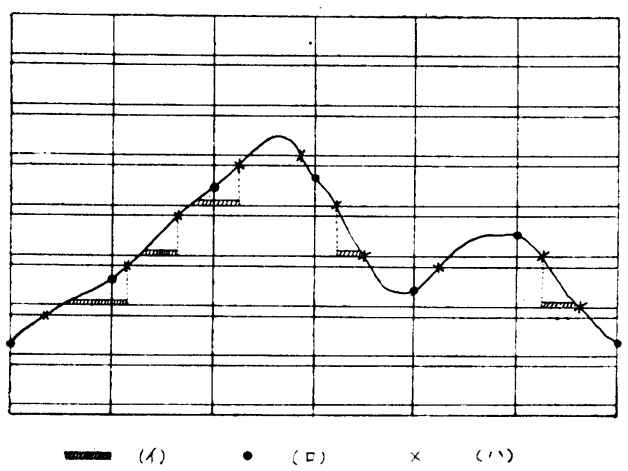

（第 23 図）路数分布の計数様式

2 者は前者に比べて䛇差心大きいように見えるが，測定 長がある程度以上におきければ，大きな差はない，素た 第6汹の上うに水や小さい球を用いて度数分布を求める こともできる。

\section{b) 淔接法}

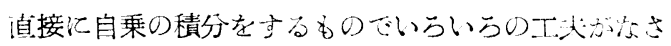
れている.

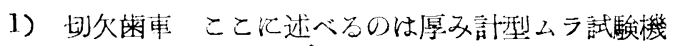

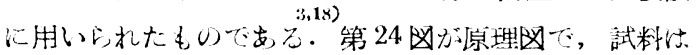

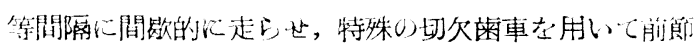

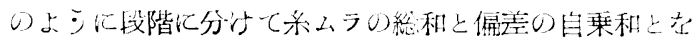
兒動的汇計算するものである。 


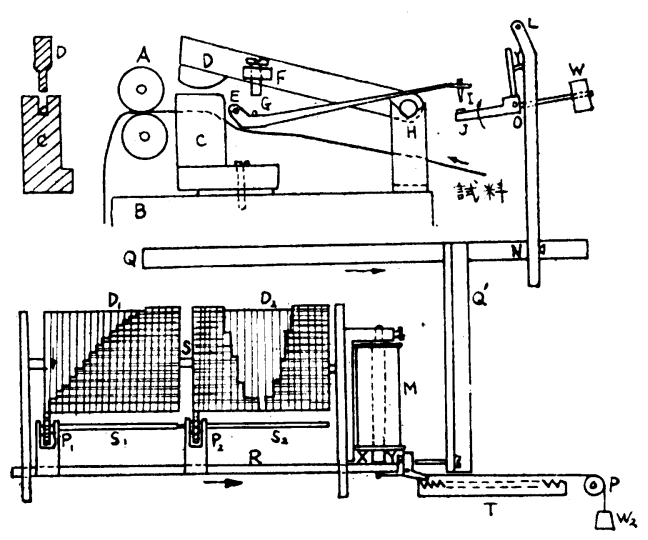

（第24四）溝付口ーラ型ムラ試験機の積算装置。

$D_{1}, D_{2}$ 汇これぞれ20個の切欠歯本からなり，これら 润じピッチー左から $0,1,2,3, \cdots \cdots 19$ Ł $45,36,28,21$, $15,10,6,3,1,0,0,1,3, \cdots \cdots 45$ 上南がついている. $D_{1} 0$

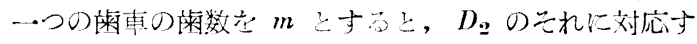

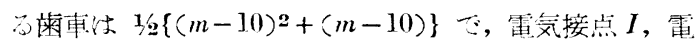
磁不 $M$ 等の作用で自動的に積算される。

$$
\begin{aligned}
& D_{1}, D_{2} \text { の読友文 } A, B \text { 上すれは， } A=K_{1} \Sigma m \text {, } \\
& B=K_{2}\left\{(m-10)^{2}+(m-10)\right\} \text { - } \\
& \sigma^{2}=\frac{1}{n} \Sigma(m-10)^{2}-\left(\begin{array}{c}
\Sigma m \\
n
\end{array}-10\right)^{2}=\frac{B}{K . n} \\
& -\left(\frac{A}{K_{1} n}-10\right)-\left(\frac{A}{K_{1} n}-10\right)^{2}
\end{aligned}
$$

2) 光切断法 測定量坸等かの方法で電流に变流， この電流文反照型検流計に通し，第25威(A)の上うな 方式て 2 個のスクリーン主通過する光舅光光電池 $P$ に

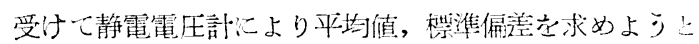

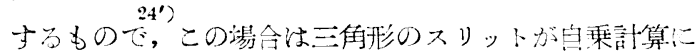

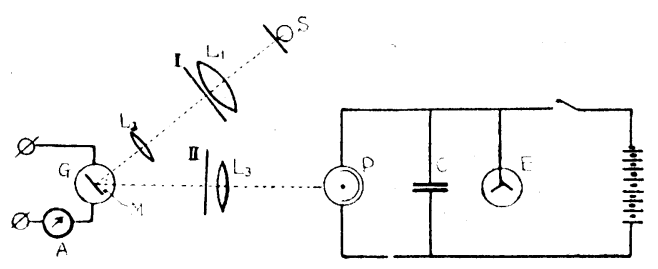

(a) 光兴的部分

(b) 電気的部分

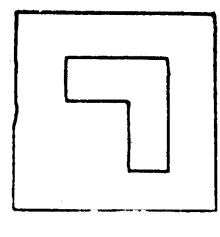

スクリーン I

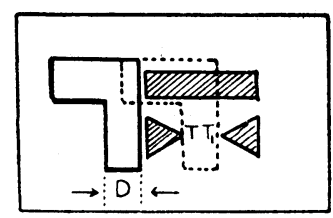

スクリーン |

(A)

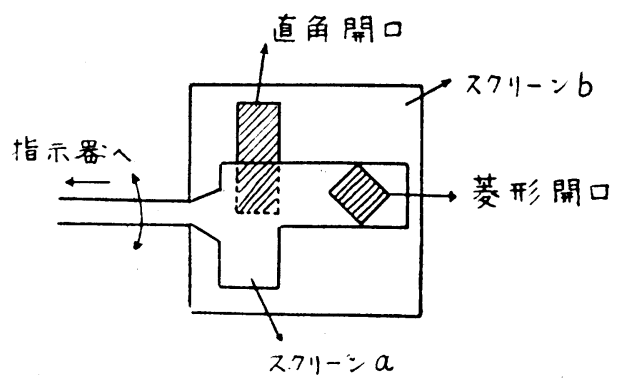

(B)

(第25汹) 靜電的積分装筐 “vitno-tester”

圧, 電流回路の聞の位相差，すなわり力率老なるべく

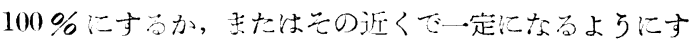

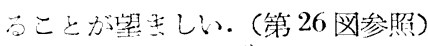

4) 真空管の特泩）真空管（例えば6B8）の特性长利 用して, 自乗淔の積分䘮行う方法が考光られる・この方 法一心 1 乗和の湯合之同様で, 後に述べるように $R-C$

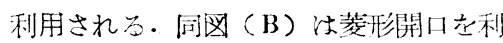
用し,Saco-Lowell のロービングテスタ に附加使用されたものである。

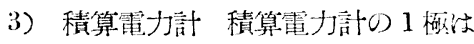
霓流，他の極は電压に比例した電流が流 れ，この積すなわ告電打比例した速度 一回転板が回転し，これが時開に刘して 積算されるようになっている・したがっ こ，この 2 個の積算電力計を用い， 1 個 以電圧線輸に一定電流老, 電流線輪心湘 定電流を流せば 1 乗和が求められ，もう 一..つの積算電力計では電瓜, 電流線輸に 共に測定電流を流せば，自乗和が得巨礼 48.i2)

。ここの際直流の積算電打尌が用いられ る上理想的でるが，交流の場合には電

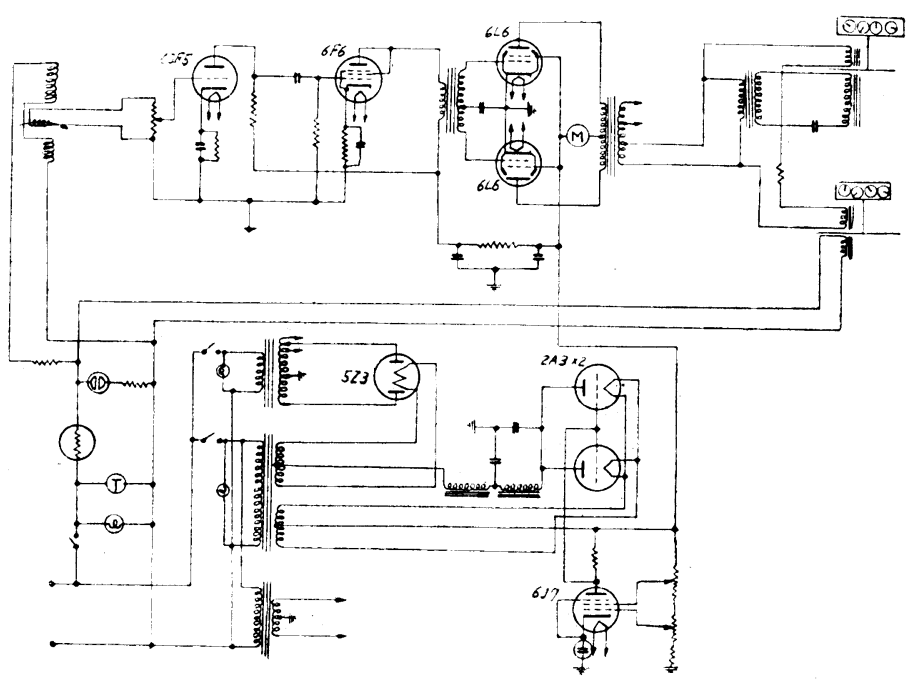

（第 26 汹）積算電力計を利用した積分回路 


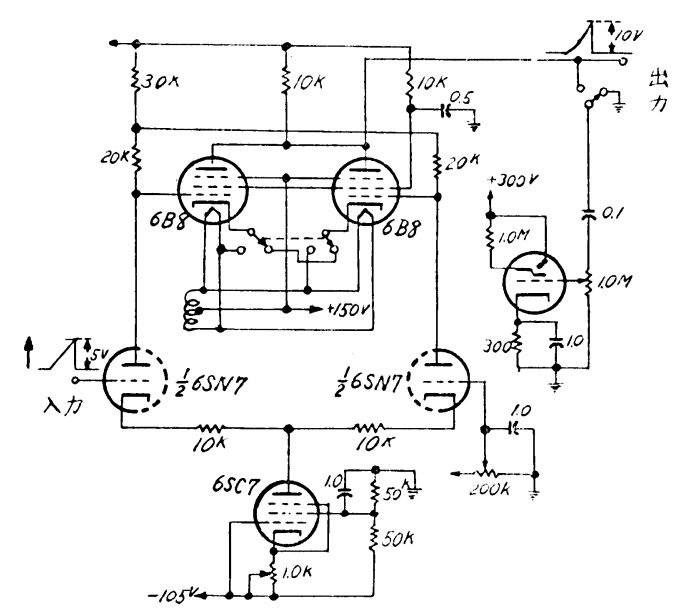

（第 27 図）真空管を利朋した自乘積分回路

回路に入れたり，電流な $C$ に貯めてメータて読むこと ができる・(第 27 艮参照)

c) 近似値推定法

以上のように自乗值の積分はいくらか複雑になるが, ランダムにとった試料の测定值が正䂓分存さしている場 合には次の簢便法によって近似的に評価できる.

1）平均偏差法 $\quad N$ 個の試料中, 艺の重量が平妁䛧 より小さいものの数を $\nu$, それら重量の和䘮 $\omega$, 全試料 の重最の和を $W$ とすれば, 平均偏差は

$$
2\left(\frac{\nu W}{N}-\omega\right) / \sqrt{N(N-1)}
$$

しかるに正規分有の晹合には

$$
\text { 楛準偏差 }=\sqrt{\frac{\pi}{2}} \times \text { 平均偏美 }
$$

であるから, 栖潐偏差 $\sigma$, および変㡖倸数 $C . V . は$

$$
\begin{aligned}
& \sigma=\sqrt{2 \pi}\left(\begin{array}{c}
\nu W \\
N
\end{array}-\omega\right) / \sqrt{N(N-1)} \\
& \left.C . V .=250.7 \sqrt{\frac{N}{N-1}\left(\frac{\nu}{N}-\frac{\omega}{W}\right.}\right)
\end{aligned}
$$

ここた $\nu, \omega, W$ む簡単に求める工夫究すれば， $C . V$. 江容易使求められる.

2) 平均レンジ法 $N$ 個の試料地犬きの等しい群 （群の大きさ $n$ ） $m$ 個にランダムに分讨て，一つの群に 打ける最大值, 最小值の差, すなわらレンジ空 $R$ 上 し, 全轻料の测定值の和在 $W$ と与ると，C.V.は

$$
\begin{aligned}
C . V . & =\frac{(\Sigma R / m) / D}{W / N} \cdot 100=\frac{n}{D} \cdot 100 \cdot \frac{\Sigma R}{W} \\
& =F \cdot \frac{\omega}{W}
\end{aligned}
$$

この式た $D, F$ の值はいらいろの大きさの群に対し て第 1 表に示してをる。

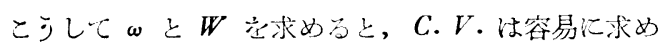

（第 1 表）

\begin{tabular}{r|c|c}
\hline$n$ & $D$ & $F$ \\
\hline 5 & 2.32593 & 215.0 \\
6 & 2.53441 & 236.7 \\
7 & 2.70436 & 258.8 \\
8 & 2.84720 & 281.0 \\
9 & 2.97003 & 303.0 \\
10 & 3.07751 & 324.9 \\
11 & 3.17287 & 346.7 \\
12 & 3.25846 & 368.3 \\
\hline
\end{tabular}

られるのである。

3) プロビット 法 第28闵の正䙺 分·在曲線がN個の 試料から得られた 上与る. $X_{1} \supseteqq x_{i}$ たる测定值 $x_{i} の$

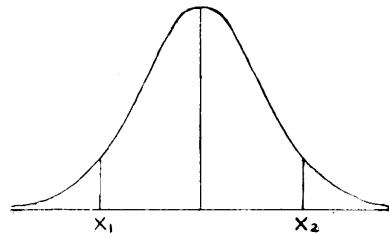

(第28図) 䜣規分·在の曲線

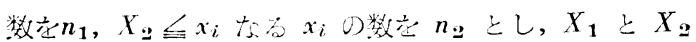

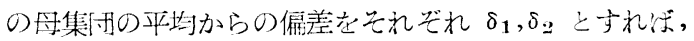
C.V.W

$$
C . V .=100 \cdot \frac{N}{W} \cdot \frac{X_{2}-X_{1}}{\delta_{1}+\delta_{2}}
$$

ここで $\delta_{1}$ と $\delta_{2}$ は $q_{1}=n_{1} / N$ と $\Omega_{2}=n_{2} / N$ に対応

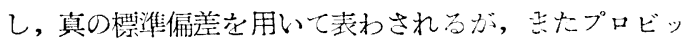
トの裴からも得られる・これは確率紙老用いて図から榄

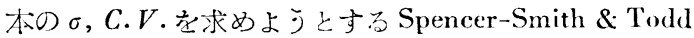
の力法と原理的には同じである。

以上の三つの方法と正統的な平方根一平均一自乘法 (root-mean-square method) との效率比較する上, 100 個の孪量を用いて平方根一平均一自乘法によって評 価した結果は, 平均偏道法では 112 個, 平均レンジ法 では128個，プロビット法で虫148個の変量についての結 果と同じで女る。これらの簡便法梳切断した個くの試料

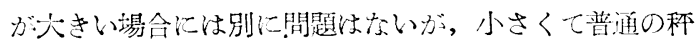
て1個つつ科量することが困難な場合には, 試料泣数個 ゔ束にして，それら束について $C . V . g$ 童求める。

束の棰成試料数圭 $g$ 個とすると, 所要の試料の C.V. は $\sqrt{g} \cdot C \cdot V \cdot g$ として求められる。

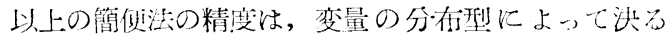
が，正挸分在の時飞江平均偏差法，てれから偏っている と平为レンジ法による精般が良いといわれている.

\section{2. 平均偏差係数}

これは通常 $U \%$ と呼济れる量で，ムラ試験機から得 られたムラ明線に执いて，高心の平均值て高さの平均㴜

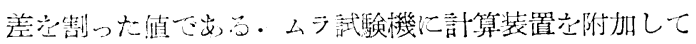




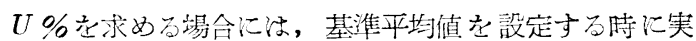
際の平均值とかがえば誤差が入ってくるのた，経験的に

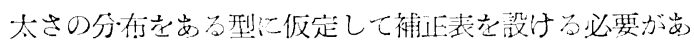

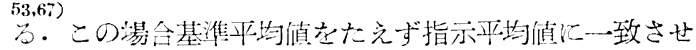
て浮動させるものも安り，この場合の補淈は平均偏羑係

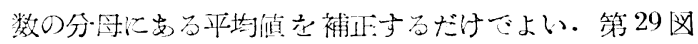
はこの関係立誇掁したものでる。
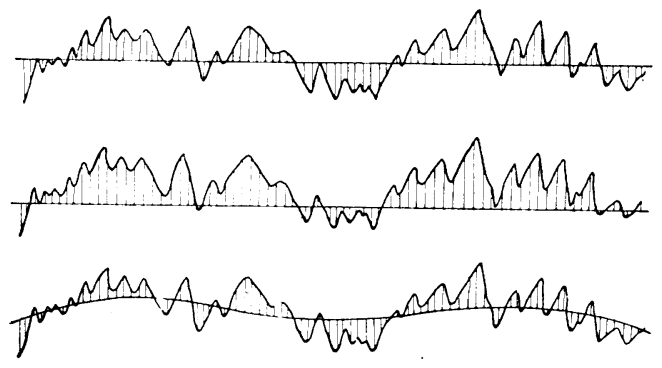

（第29図）基準平均值のとり方の差

ムラ試験機に附加する平均值, 平均偏差の言十算装置と しては, 容量 $C$, 抵抗 $R$ からなるタンク回路を用いたも のが多いここの場合普通は数 $\min$ 程度の時定数をもたせ るのでもるが，リークさせないて大きい $C$ 齐用いて， 证しく任意の長さの測定部分の積分を行扮うとするもの

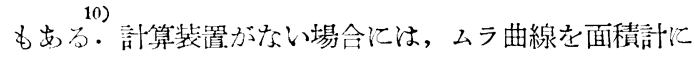
より追跡してU\%が求められる。

\section{3. 平均レンジ法}

ここに述べる方法は，U\%方匴する装置のない時に $U \%$ の代りになる量をムラ曲線から求めようとするも のである・すなわちムラ曲線を長さ方南に定長に区分し て, 各部分について曲線の振巾の最大值, 最小值の差を とり，それ索曲線の全部分伅ついて平均した值をムラ曲 線の平均值 (Pacific evenness tester たは用いるローラ の溝门，倍䒺，ゲージ等を利用して求める゙) で割った值 で average percent unevenness とよばれるものである。

これは試料なランダムにとっていないという点で, 本章1節 c)，2) の方法とは異なり，徉って栖淮偏差の 推定はできないが，実用上は品啠管理の点から便利な尺 度である。

\section{4. 变動 指数}

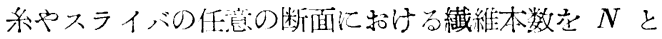
すると，3章2 節b) て述べたように,これはポアンン分

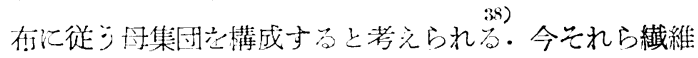
が各断面に完全にランダムに分在してい方場合を理想的 な配列として，これらの栖淮偏差 $\sigma$, 扎よび变動倸数 $C \cdot V \cdot$ はこれでれ

$$
\sigma=\sqrt{N_{0}}, \quad C . V .=\frac{100 \sigma}{N_{0}}=\frac{100}{\sqrt{N_{0}}}
$$

このようにC.V.の値は繀維の本数きたはスライバや 系の太さが細くなるにつれて大きくなるはずだるが， 実際の值はこの上うなムラの大きさに，备工程において ランダムな分在から偏らせるような原因が作用するから

$\sigma$ (現実值) $>\sigma$ (理想值)

$C . V$. (現実值) $>100 / \sqrt{N_{0}}$

これらの式で， $N_{0}$ 㥪面における平均瀻維入数であ ๖.

ここで現実の C.V. 在 $V$ 上して，次のようにおく.

$$
V=\frac{100 K}{\sqrt{N_{0}}}
$$

すなわわ

$$
K=\frac{V \sqrt{N_{0}}}{100}
$$

この $K$ はいわゆる变動指数と呼ばれるもので, 実際 には瀻維本数 $N$ より番手の方が便利なのだ, 繊維の断 面積の変動老無視し

$$
K=\frac{V}{100} \sqrt{\frac{\text { 糸の平均番手 (denier) }}{\text { 平均瀻維番手 (denier) }}}
$$

を用いると，結局

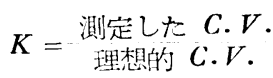

であな・

一般にスライバから系に至る工程に执いて，えれらの

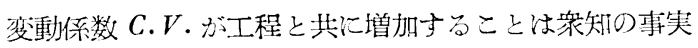
てをあるが，C.V.の変化だけから工程管理圭することは なかなか難かしい，それから中間製品の番手疮考不入 れてこの番手に拈ける理想的な $C . V$. の值と比較して工 程を検討しょうとしたので女る。この方法はきわめて便 利で，横軸に工程番号を緃軸に $K$ 文々って図妾作ると， 急に $K$ の值の増加する所次陷のまることが分る・ま た番手の異なる糸を公平な基準て比較しようとするのに る利用されるわけである。

\section{5. 調和解析}

系ムラに含まれる周期性を検!出るために，他の分野 で用いられている調和解析が利用された。い等間隔に とられた钼測值を

$$
U_{0}, U_{1}, U_{2}, \cdots \cdots
$$

とする・この中から长さ $q$ の周期な調べるために， $U_{0}$, $U_{q}, U_{2 q}, \cdots \cdots$ の平均求める。次に $U_{1}, U_{q+1}, U_{2 q+1}, \cdots$ の平均在取り，かくして $U_{q-1}, U_{2 q-1}, U_{3 q-1}, \cdots \cdots の$

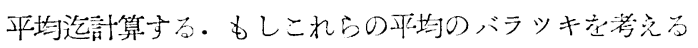
と $q$ また法 $q$ の测数以外の周期の振巾やランダムた变 動は相当に減少与るから，qまたは $q$ のむる約数の周期 
が観测中にある時にのみ，上述の $U$ の平均怔相亚に大 きくばらつく、气こでかかる計算かいるいるの長さの周 期について行党ば，極大据门在生じるすが大部分のも つ上もな周期症与兄こ上汇なる。

しかし $q$ 在气の約数上区別する必要が女子から，と れらの平均值总調和解析与。.

$U_{0}, U_{1}, U_{2}, \cdots \cdots U_{q-1}$ 在气れらの平均值上寸る上，振灲 $R$ は

$$
R^{2}=A^{2}+B^{2}
$$

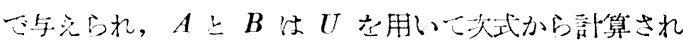
$\vec{\sigma}$.

$$
\begin{aligned}
& A=\frac{2}{q} \sum_{r=0}^{q-1} U_{r} \cdot \cos 2 \pi \frac{\gamma}{q} \\
& B=-\frac{2}{q} \sum_{r=0}^{q-1} U_{r} \cdot \sin 2 \pi-\frac{\gamma}{q}
\end{aligned}
$$

これらの計算はきわめて面倒てする。これ省機械的心 求めようとして考案されたのが Grating Periodograph

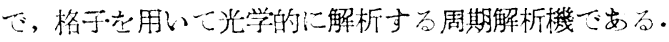

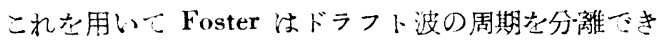
たように見えた方，スライバの各区分汇よって基楚周期 が異なった值走し，ドラフト波の複雑性主立証しだ。

\section{6. コレログラム}

ムラ曲線やスライバきたは糸の一定長のものの重量在

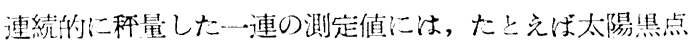
の活動のような現象似て見かけ上の周期性はむっても

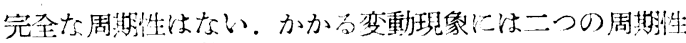
の型が考号られ。

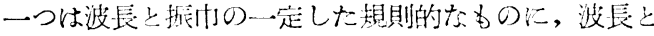

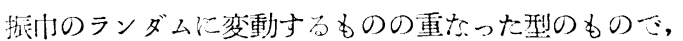
かかる場合には本章 5 節の調和解析によって前者だけ充 分離して，波長きたは周期救めることがでる。 他の一つ沬Yule の暗示したもので, 任意の扮動采に 外力が加わって，振巾，位相，波長がとるに变動寸る現

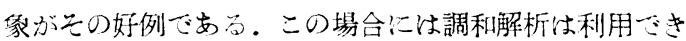
ない：ここで考えられたのが采列相関保数こある。

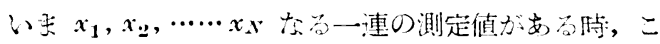

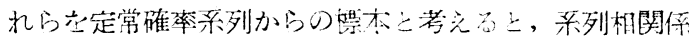
数 $\gamma_{k}$ 沈

$$
\gamma_{i}=N_{N-k}^{1} \sum_{i=1}^{N-k}\left(x_{i}-\bar{x}_{1}\right)\left(x_{i+k}-\bar{x} \mathbf{g}\right) / S_{1} S_{2}
$$
ここー゙

$$
\begin{aligned}
& x=\sum_{i-1}^{N-k} x_{i}, \bar{x}_{i}={\underset{i}{N}-k+1}_{N-k}^{N} x_{i}, \\
& S_{1}^{2}={ }_{i=1}^{N-k} \frac{N-k}{\left.N-x_{i}-x_{1}\right)^{2}}, S_{2}^{2}=\stackrel{\sum}{N}=k+1_{N-k}^{N}\left(x_{i}-x_{2}\right)^{2}
\end{aligned}
$$

ここた $\gamma_{k} の k$ に関するグラフォコレログラムとい j.
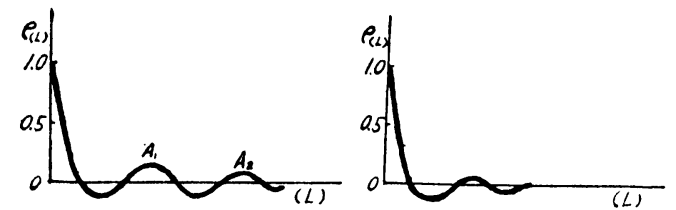

(第 30 図) コレログラム

この一例卒示すと，第30図のようなものてある。ムラ

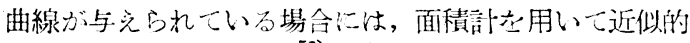
に相関倸数な求め万方法多女る。

この采列相関倸数妾光学的な方法厄求めようとして， Correlation Periodooraph が考案され，ドラフトムラ の研究に利用された。

\section{7. $V-L, B-L$ 曲線}

糸么ラは長周期のわのと, 短周期のものぶ重なってい 万の一, 長さ $L$ 內の級內变動倸数 $V(L)$, 長さ $L$ の平

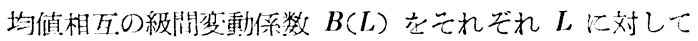
网示す名と，この系ムラの周期性がはっきりする。ここ ○ $\boldsymbol{V}-\boldsymbol{L}$ 曲線は $L$ の增加之共にあ尚值に漸近し， $R-I$ 曲線は減少して0!二漸近し，任意のLについ?

$$
[V(L)]^{2}+[B(L)]^{2}=[V(\infty)]^{2}=[B(0)]^{2}
$$

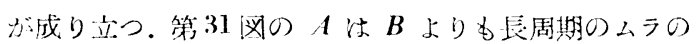

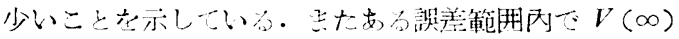

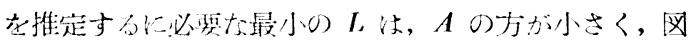

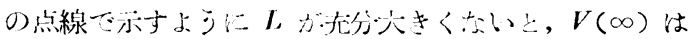
同じて子異なった $V$ 亲示すこ上にたるのて注望しなけ ればならない。

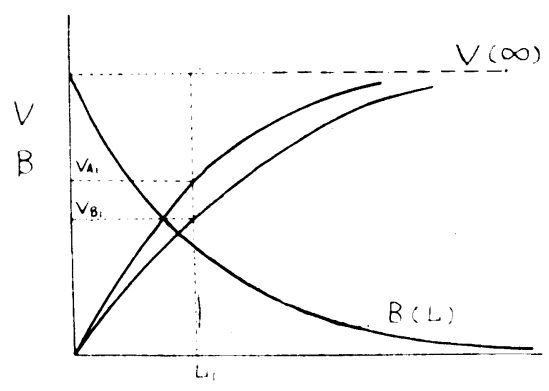

（第 31 汹]） $V-L, B-I$ ，曲線

\section{8. その他}

本篔（節 a) に述ベたの上同様に，ベローズに漸惊し た記録ペンの他方の接触于が，系の太さに比例した苗状 の部分に触れ名上うにし，带状の各部は絕螕体下分剖し て, これらの部分立接触于が通過する时に, これに附加 して, 女る部数器が作動方名方式尘用い\%場合, 平均偏

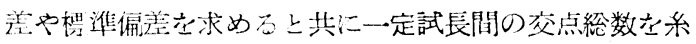


ムラの指敉とする方法は，周期性劣含んたいる点から面 白い，それから系の太さによって動くペンがある限界以 上に振れる時, この振れた回数文計数する方式は本章 1 節 c)，3）のプロビット法の变形上考えられる。

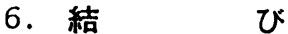

以上で禾ムラについて大要を述べたが，本稿龺する に当って交献を快よく見せて戴いた東洋レーヨン本部研 究所扣よび鐘紡紡織試験所の方々に謝意を表するととも に，本稿を校閲して戴いた藤野敎授に感謝致します。

\section{文献}

1) 新井幸長，“紡績試験論と実務”P.4.03 (1952)

2) 同 上, P. 417 (1952)

3) Anderson, S. L., Cavaney, B., Foster, G.A.R., and Wornersley, J. R., J. Text. Inst., 36, T. 253 (1945)

4) Anderson, Cavaney, Foster, and Gregory, J., ibid., 36, T. 191 (1945)

5) Balls, W. L., "Studies of Quality in Cotton", London, 1928, Ch. VII.

6) Beevers, W.I.R.A., Publication, 186 (1948)

7) Casby, R.F., Text. World, 102, 98 (1952)

8) Chakrabarti, B.K., Text. Res. J., 23, 99 (1953)

9) Chance, Huges, MacNichol, Sayre and Willians; "Wave-Forms", P. 678 McGraw Hill, (1949)

10) Chandler, N. H., Text. World, 102, 96 (1952)

11) Cox, D. R., Ingham, J., J. Text. Inst., 41, P.376 (1950)

12) コッス糸ムラ試験機說明書

13) Elting, J. P., Burnes, J. C., Text. Res. J., 20, 773 (1950)

14) Ewles, J. Text. Sci., 2, 100 (1928)

15) “Fielden-Walker”糸ムラ試験機のカタログ

16) Fielden, Dielectric Comparator, B.P. 619,534, (1946)

17) Foster, G.A.R., J. 'Text. Inst., 21, T. 18 (1930)

18) ibid., 26, T.37 (1936)

19) ibid., 36, T. 229 (1945)

20) Foster, G. A. R., Martindale, J. G., J. Text. Inst., 37, T. 1 (1946)

21) Foster, G. A. R., ibid., 41, P.360 (1950)

22) ibid., 42, T.335 (1951)

23) Frenzel, W., Germann Patent, 353,086 (1922) : Leipziger Monats, Text. Indus., 37, 166 (1922)

24.) Goodings, A. C., J. Text. Inst., 22, T.1 (1931)

24') Germanns, IR. F. H., ibid., 41, P. 467 (1950)

25) Gregory, J., ibid., 42, T. 489 (1951)

26) Gregory, J., Tyson, A., ibid., 42, T. 147(1951)

27）久田, 野崎, 渡辺, 安藤, 上西, 名工技試報告 2,1 (1953)

28）同上纎維機械学会誌 6,553 (1953)

29）同上名工技試報告 3，245 (1954)

30) Hasler, A., Honegger, E., Text. Res. J., 21, 73 (1954)

31）“豊和型光電管系ムラ試験機”繊維測定研究グル ープ, 资料 6,9 頁

32) Huberty, A., J. Text. Inst., 43, P. 156 (1952)

33）石原，日本機械学全誌，54，5 (1951)

34）JSIF (日本紗績検査協会) No. 3，20 (1952)
35) JIS, L 1101 (1953), 輸出綿糸の検査標準, 改正 昭和 28 年 12 月 25 日

36) 加藤, 城奥, 吉田, 福井大学卫学部報告, 1 号, 17頁, (1952)

37) Martindale, J. G., J. Text. Inst., 32, T.71 (1941)

38) ibid., 36, T.35 (1945)

39) ibid., 36, Т. 213 (1945)

40) Martindale, J. G., J. Text. Inst., 37, P.351 (194.6)

41) ibid., 41, P.310 (1950)

4.2) Matthew, J. A., ibid., 23, T. 55 (1932)

4.3) Matthew, J.A., Rajehenbaum, N. B., and Spencer-Smith, J. L., ibid., 41, P. 486 (1950)

44) Monf ort, F., Neirynck, T., ibid., 42, P. 75 (1951)

45) Mont"gomery, D. J., Milloway, W. T., Text. Res. J., 22, 729 (1952)

$\left.45^{\prime}\right)$ 三平，緎維機械学全誌，6，283(1953)

46) 森, 纎維工業学全誌, 2,268 (1936)

47) 野崎, 峰尾, 安藤, 機械試験所々報, 5, 211 (1951)

48) 野崎, 長谷川, 機械試験所名古屋支所, 技術二工 一ス，1952年 1 月

49）野崎, 裂野, 安藤, 長谷川, 名工技試報告 $2,1(1953)$

50) 野崎, 峰尾, 加藤, 愛野, 安藤, 同上 2,149 (1953)

51) 応用力学全編集, 応用統計学, 7 章39頁 (1949)

52) 押田, 船货集誌, 22, 3，(昭19)

53) "Operating instructions for Ust $r$ Inte rator $^{2}$ I'TG1."

54) Oxley, A. E., J. Text. Ins'., 13, T.54 (1922)

55) "Pacific Evenness Tester," the need and use of instrument.

56) Rusca, R. A., Tex.. Res. J., 20, 780 (1950)

57) Saxl, I. J., J. Text. Itst., 26, T. 77 (1935)

58) Saco-Lowell, 'Text. Recorder, 63, 38 (1945)

59）白樫，山上，緎維兴全誌，6，141（1950）

60) 白樫，山口，繊維学全誌，7，248 (1951)

61) 同上 8,253 (1952)

62) Spencer-Smith, J. L., Todd, H. A.C., J. T.xt. Inst., 28, T. 21 (1937)

63) Stanbury, G. R., ibis., 23, T. 35 (1932)

64.) Stout, II. P., ibill., 41, P. 433 (1950)

65) Strother, F. P., Electronics, 25, 110 (1953)

66) Starr, A. T., Wirt less Eng. \& Exp. Wireles=, 9, 615 (1932)

67) 角屋, 藤井, 明石, 浅野, 石沢, 緎維機械学会昭 和 28 年春季大全発表，纎維測定研究グループ，资 料 35, 121 頁

68) Tippett. Biometrika, 17, 386 (1925)

69) Townsend, M. W. H., Cox, D. R., J. Text. Inst., 42, P. 107 (1951)

70）豊田自動繊機研究報告，2，7 (1952)

71) Truitt, J.A., Rayon \& Syn. Text., 32, 40 (1951)

72) Vose, R. W., Pulmer, C. H., J. Text. Inst., 36, T. 177 (1945)

73) Walker, P. H., ibid., 41, P. 446 (1950)

74.) W. \& J. Whitehrad Ltd., O. M. Steward \& C. Smith, E. P., 343,215

75) Young, Ency Brit. Suppl. to 4th, 6th Ed. 1824, Articles on Chromatics.

76) Yule, G. Udny Phil. Trass. Roy. Soc., A., 226,267 (1927) 